\title{
International Economics in Terms of Rattan Industry
}

\author{
Ni Made Ayu Sanjivani A. D \\ Faculty of Business and Economics, University of Surabaya \\ aayusanjivani@gmail.com
}

\section{Introduction}

Rattan is the palm family that lives in up to $3,000 \mathrm{~m}$ from the sea level and has around 600 species with 13 genera. It can be found in tropical regions such as Africa, Australia, and Asia (Rattan facts and information, n.d.) Rattan is a non-timber forest product that benefits the developing country in saving the forest. In Indonesia, rattan is important to combat global warming, overcome the soil erosion, save the natural forests, and increase the access to the water reservoir as the aim of the Environmental Initiatives. Indonesia is the largest rattan furniture exporter with 80 percent on the global market followed by China and Vietnam on the Third. But, in 2011, the Indonesia Ministry of Commerce banned the export of raw rattan to support forest conservation and sustainably to save the rattan industry in Indonesia. However, the export banned of raw rattan result in smuggling on the raw rattan (Pratono, 2019)

An absolute advantage is the capability to produce a product more efficiently than the other country. A country that can produce a product with lower marginal cost (Boundless Economics, n.d.) and with better technology is more likely to have an absolute advantage in the production of that item. Comparative advantage is the ability to produce a product with a lower opportunity cost over other country. A country can have a comparative advantage in which it has an absolute disadvantage. This is one reason why the comparative advantage concept is more powerful than the absolute advantage concept (Reinert, 2012) The Global Value Chain provides local firms in the underdeveloped country an opportunity to transform their business into international operations by combining domestic and foreign intermediate inputs. It also can provide better access to information, open a new market, and build an opportunity to learn fast technology and skill acquisition (Pratono, 2019) 


\section{Conclusion}

The patterns of comparative advantage determine patterns of trade in the world economy and generate mutual gains from trade (Reinert, 2012) For example, Thailand and Indonesia. Both are producing rattan and sugar; however, the differences in supply conditions in which one country producing a product at a lower price compared to the other country result in the product being imported to the country with the high price of the product. For instance, Indonesia's rattan price is cheaper than in Thailand and so Thailand chooses to export rattan rather than produce it. Indonesia has a comparative advantage for producing rattan compare to Thailand and vice versa. Thailand has a comparative advantage for producing sugar and results in trade between the two countries. The International economist called this kind of activity as gains from trade which benefit both Thailand and Indonesia. GVC shows how cross-cultural collaboration negotiates with price mechanism, which involves at least three typologies, such as e-market driven, buyer driven, or producer driven (Pratono, 2019) Among these three typologies in which relevant to promote a fair trade is the buyer-driven. The buyer-driven involves multinational companies as the intermediaries and the sales agent to the end customers and since the rattan furniture is exported to the developed countries such as Europe, the US, and Japan. The semi-finished product is supplied from the small rattan manufacturers in the developing countries to the large finished product manufacturer for the lead firms in developed countries. It will benefit both the rattan manufacturers from the developing countries and the lead firms as the sales agent since the lead firms stay close with the end customer which enables them to understand the market preference and develop design innovation and build a strong relationship. Besides, the lead firms offer an opportunity to the partner in developing countries since the buyer-driven describe the role of sale agents in hiring professional design to respond the customer demand and the emerging countries have lots skills that need to be improved, the lead firms transfer the innovation to the manufacturers and weavers in developing countries (Pratono, 2019). 


\section{References}

Boundless Economics. (n.d.). Retrieved from Lumen:

https://courses.lumenlearning.com/boundless-economics/chapter/introduction-tointernational-trade/

Pratono, A. H. (2019). Cross-cultural collaboration for inclusive global value chain: a.

International Journal of Emerging Markets. Retrieved from https://doi.org/10.1108/

Rattan facts and information. (n.d.). Retrieved from WWF:

http://greatermekong.panda.org/our_solutions/projects/sustainablerattan/factsinformat ion/

Reinert, K. A. (2012). An Introduction to International Economics: New Perspective on the World Economy. New York: Cambridge University Press. 